\title{
Co-digestion of sewage sludge from external small WWTP's in a large plant
}

\author{
Stanisław Miodoński ${ }^{1, *}$ \\ ${ }^{1}$ Faculty of Environmental Engineering, Wroclaw University of Science and Technology, \\ Wybrzeże Wyspiańskiego 27, 50-370 Wroclaw, Poland
}

\begin{abstract}
Improving energy efficiency of WWTPs (Waste Water Treatment Plants) is crucial action of modern wastewater treatment technology. Technological treatment process optimization is important but the main goal will not be achieved without increasing production of renewable energy from sewage sludge in anaerobic digestion process which is most often used as sludge stabilization method on large WWTP's. Usually, anaerobic digestion reactors used for sludge digestion were designed with reserve and most of them is oversized. In many cases that reserve is unused. On the other hand, smaller WWTPs have problem with management of sewage sludge due to lack of adequately developed infrastructure for sludge stabilization. Paper shows an analysis of using a technological reserve of anaerobic digestion reactors at large WWTP (1 million P.E.) for sludge stabilization collected from smaller WWTP in a co-digestion process. Over 30 small WWTPs from the same region as the large WWTP were considered in this study. Furthermore, performed analysis included also evaluation of potential sludge disintegration pre-treatment for co-digestion efficiency improvement.
\end{abstract}

\section{Introduction}

Dynamic development of renewable energy is one of the priority of energy Policy In Poland. By 2020, renewable energy will be $15 \%$ of the total electrical energy produced in Poland [1]. Between 2010 and 2014 the contribution increased from 10.2\% to $11.8 \%$ [2]. All activities focused on renewable energy production increase are good way to reduce greenhouse gases emission and are part of sustainable development policy. Anaerobic digestion is one of the most popular methods for renewable energy production. In this process, because of proper conditions and special equipment, activity of naturally occurring bacteria leading to organic carbon mineralization is multiplied. Digestion takes place when organic materials decompose in an oxygen-free environment. During digestion, various microbes use the organic matter such as animal manure, sewage sludge, wasted food and other organics in the absence of oxygen. The process can be controlled and enhanced through chemistry and engineering [3]. The co-digestion process consists on simultaneous digestion

\footnotetext{
* Corresponding author: stanislaw.miodonski@pwr.edu.pl
} 
a few materials where one is the basis material (e.g. sewage sludge, swine manure) and the others are additional material (e.g. food waste, grease trap sludge) [4,5]. A specific case of co-digestion is situation when basis and additional materials are both sewage sludge, for example basis material form large WWTP and additional material are form transported from medium and small WWTPs located near a large plant. Despite similar characteristics of all used materials, operated process will be still considered as a co-digestion.

Paper presents potential development proposals for use available anaerobic digestion reactors volume for co-digestion process with sewage (excess) sludge form small and medium WWTP, localized nearby a large object. This scenario helps to solve the problem of sewage sludge produced in small and medium WWTP and allows to increase renewable energy production on large WWTP (in next sections called as "Central Plant"). The study and technological analysis were based on real data from a large WWTP in Lower Silesia Region in Poland (1 million P.E.) and medium and small WWTP localized in nearby towns. As a next step of performed analysis, also potential impact of thermal disintegration of excess sludge before an anaerobic digestion process was investigated.

\section{Materials and methods}

\subsection{Central Plant, basis sludge for digestion}

Central Plant is a municipal WWTP with capacity of 1000000 p.e. Plant is equipped with an 6 anaerobic digestion reactors fed with mixed of primary and excess sludge. Limited amount of produced gas can be stored, otherwise it is immediately used for energy production in CHP units.

\subsection{Small WWTPs, additional sludge for digestion}

For performed analysis, objects form North east region of Lower Silesia located nearby to the Central Plant were selected. Analysis includes WWTPs from:

- Oleśnicki district,

- Oławski district,

- Trzebnicki district,

- Wołowski district,

- Wrocławski district.

In the area taken into consideration, 31 objects were identified. Most of this plants are objects without primary sedimentation. This plants produce only excess sludge which has relatively poor gas production parameters during digestion process.

\subsection{Basis of the analysis}

In this experiment impact of distance between Central Plant and selected smaller plants was tested along with further advantages from excess sludge disintegration use. For further analysis following variants were adopted:

- Variant 0 - basis scenario. No additional sludge delivered and none excess sludge disintegration method used.

- Variant 0D - No additional sludge delivered. Thermal disintegration of excess sludge used.

- Variant 25 -Sludge was delivered only form smaller WWTP localized within $25 \mathrm{~km}$ radius from the Central Plant. No disintegration of excess sludge used. 
- Variant 25D -Sludge was delivered form smaller WWTP localized within $25 \mathrm{~km}$ radius.. Thermal disintegration of excess sludge used.

- Variant 50 - Sludge was delivered form smaller WWTP localized within $50 \mathrm{~km}$ radius from the Central Plant. No disintegration of excess sludge used.

- Variant 50D -Sludge was delivered form small and medium WWTP localized within $50 \mathrm{~km}$ radius from the Central Plant. Thermal disintegration of excess sludge used.

\subsection{Kind of disintegration}

Presented assumptions were created based on use of high efficiency thermal or thermo-chemical sludge disintegration. That kind of disintegration allows to increase gas production form excess sludge by $60 \%$ [11]. Due to necessary transfer this process form laboratory to full scale object, $50 \%$ increase in gas production was assumed.

\section{Results}

\subsection{Technological reserves of Central Plant's digesters.}

For analysis, real data from last three years of anaerobic digestion process operation at the Central Plant was used. Based on this data average and percentile $85 \%$ was determined. Obtained values were basis for further proceedings presented in following sections. Table 1 summarizes sewage sludge parameters divided into thickened primary sludge and thickened excess sludge.

Table 1. Sewage sludge parameters.

\begin{tabular}{|c|c|c|c|c|c|c|c|}
\hline & \multirow{2}{*}{ Flow } & \multicolumn{3}{|c|}{ Concentration } & \multicolumn{3}{|c|}{ Load } \\
\hline & & COD & TSS & VSS & COD & TSS & VSS \\
\hline & $\mathrm{m}^{3} / \mathrm{d}$ & $\mathrm{gO}_{2} / \mathrm{m}^{3}$ & $\mathrm{kgTSS} / \mathrm{m}^{3}$ & $\mathrm{kgVSS} / \mathrm{m}^{3}$ & $\mathrm{kgO}_{2} / \mathrm{d}$ & $\mathrm{kgTSS} / \mathrm{d}$ & $\mathrm{kgVSS} / \mathrm{d}$ \\
\hline \multicolumn{8}{|c|}{ Thickened primary sludge } \\
\hline Avg. & 708.9 & 75136 & 57.7 & 44.5 & 53069 & 40709 & 31337 \\
\hline $\mathrm{P} 85 \%$ & 742.4 & 86434 & 68.4 & 49.0 & 53776 & 41416 & 29806 \\
\hline \multicolumn{8}{|c|}{ Thickened excess sludge } \\
\hline Avg. & 396.2 & 63086 & 56.1 & 40.2 & 25318 & 22146 & 15829 \\
\hline P85\% & 507.1 & 67236 & 59.9 & 42.4 & 30616 & 28486 & 19681 \\
\hline \multicolumn{8}{|c|}{ Mixed sludge } \\
\hline Avg. & 1105.1 & 68546 & 57.0 & 42.9 & 75573 & 62855 & 47166 \\
\hline P85\% & 1184.7 & 78286 & 62.3 & 45.1 & 81793 & 67986 & 48454 \\
\hline
\end{tabular}

Table 2 shows digested sludge parameters collected in the same period as previous data. in the same way and from the same. Parameters determination was also the same as in primary and excess sludge. In analysed period average gas production was $20142 \mathrm{Nm}^{3} / \mathrm{d}$ and gas had methane concentration level at about 58\%.

One of the most important parameters describing work regime of anaerobic digestion reactor is Organic Loading Rate (OLR). Safe operating range if from $0.7 \mathrm{~kg} \mathrm{VSS} \mathrm{m} \mathrm{d}^{-1}$ to $5.7 \mathrm{~kg} \mathrm{VSS} \mathrm{m}^{3} \mathrm{~d}^{-1}$ [6]. Average OLR form analysed period was $1.1 \mathrm{~kg} \mathrm{VSS} \mathrm{m}^{3} \mathrm{~d}^{-1}$. In 2016 
increase of OLR was noticed (average in $20161.41 \mathrm{~kg} \mathrm{VSS} \mathrm{m}^{3} \mathrm{~d}^{-1}$ ). This was due to the exclusion from the operation one of the anaerobic digestion reactor, due to technical issues.

Table 2. Digested sludge parameters.

\begin{tabular}{|c|c|c|c|c|c|c|c|c|c|}
\hline \multirow{2}{*}{} & \multirow{2}{*}{ Flow } & \multicolumn{5}{|c|}{ Concentration } & \multicolumn{3}{c|}{ Load } \\
\cline { 2 - 10 } & & COD & Alk. & VFA & TSS & VSS & COD & TSS & VSS \\
\cline { 2 - 10 } & $\mathrm{m}^{3} / \mathrm{d}$ & $\mathrm{gO}_{2} / \mathrm{m}^{3}$ & $\mathrm{gCaCO}_{3} / \mathrm{m}^{3}$ & $\mathrm{gCH}_{3} \mathrm{COOH} / \mathrm{m}^{3}$ & $\mathrm{~kg} / \mathrm{m}^{3}$ & $\mathrm{~kg} / \mathrm{m}^{3}$ & $\mathrm{kgO}_{2} / \mathrm{d}$ & $\mathrm{kg} / \mathrm{d}$ & $\mathrm{kg} / \mathrm{d}$ \\
\hline Avg. & 1044 & 34696 & 3520 & 306 & 35.0 & 21.3 & 36197 & 36574 & 22243 \\
\hline P85\% & 1082 & 37943 & 3709 & 287 & 39.2 & 23.2 & 38685 & 38868 & 23095 \\
\hline
\end{tabular}

Hydraulic Retention Time (HRT) was next parameter analysed in this study. Usually, HRT value should be about 15-20 d for mesophilic digestion [7]. For further consideration maximal HRT value $(20 \mathrm{~d})$ was assumed. Average HRT is $42 \mathrm{~d}$ but that value since 2013 drops systematically as HRT is being shortened. For that reason, reliable HRT was adopted like its average value in 2015 (38.2 d). In 2016 HRT was shortened from reason explained above.

Parameter describing effect of anaerobic digestion and sludge stabilization is percentage of organic matter reduction. In EPA guidelines inform that parameter for properly stabilized sludge should be over 38\%. [8]. Fig. 1 shows monthly average of VSS reduction during analysed period. Only one value was lower than $38 \%$ (black square), in other cases values were clearly higher than the minimum value.

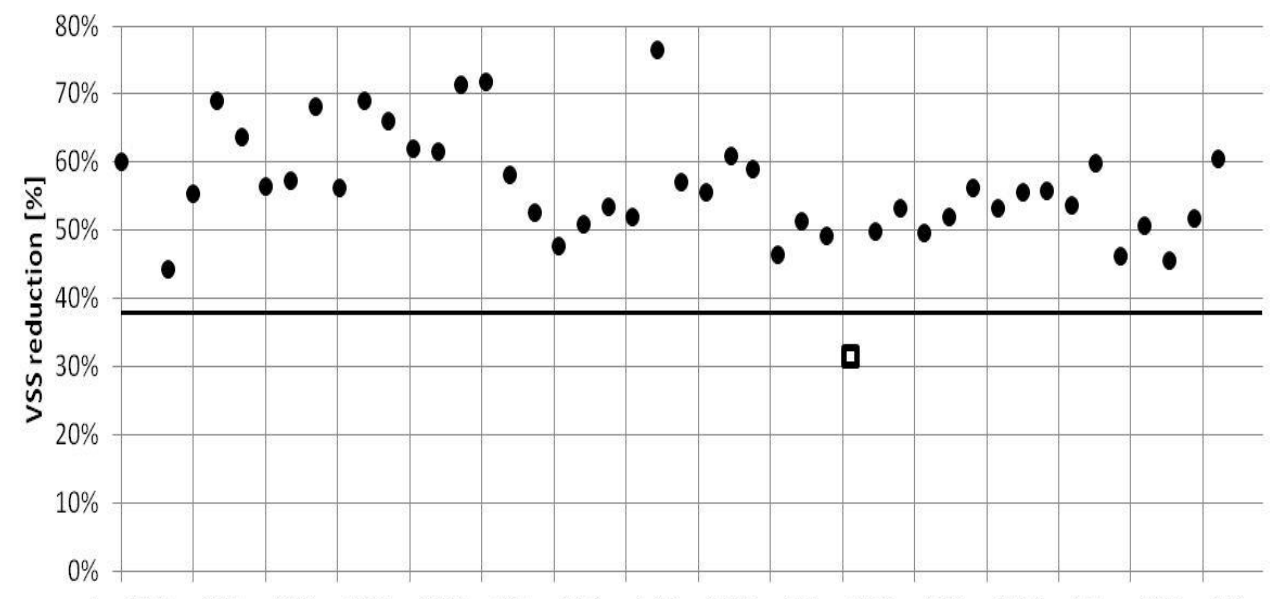

Jan-13 Apr-13 Jun-13Sep-13Dec-13Mar-14Jun-14 Sep-14Dec-14Mar-15Jun-15 Sep-15Dec-15Mar-16Jun-16Sep-16

Fig. 1. Monthly average VSS reduction.

Last of the analysed parameters was Volatile Fatty Acids (FVA) to alkalinity ratio in digested sludge. Extreme value of this parameter is $0.3 \mathrm{gCH}_{3} \mathrm{COOH} / \mathrm{gCaCO}$. Average value for analysed period was 0.087 and that value is almost 3.5 times lower then limit value.

Performed multi-parameter analysis shown that the anaerobic reactors work under stable conditions and whole process have possibility and potential for addition of external stream of sewage sludge. 


\subsection{Sludge production on analysed area}

Initially, for the analysis all WWTPs from 6 districts were used and 31 objects were identified. According to the assumptions of the analysis, two distance range from the Central Plant was chosen: $25 \mathrm{~km}$ and $50 \mathrm{~km}$. At this stage 3 objects located in bigger distance than $50 \mathrm{~km}$ away and were removed from the list. Among remaining 28 smaller WWTPs, 14 of them was closer to the Central Plant than $25 \mathrm{~km}$. Fig. 2 shows localization of analysed plants with circles marked with $25 \mathrm{~km}$ and $50 \mathrm{~km}$ radius and cantered on Central Plant. Based on data from National Program for Municipal Waste Water Treatment (NPMWWT) mass of sewage sludge from each WWTP was determined [9]. Typical VSS and TSS values for considered sludge streams were assumed, $75 \%$ and $15 \%$ respectively. Transportation cost was assumed equal 3.00 PLN/(km Mg $)^{-1}$ Effect of the calculation was shown in table 3 .

Table 3. Daily sludge production form medium and small WWTP.

\begin{tabular}{|c|c|c|c|c|}
\hline Distance & TSS & VSS & $\begin{array}{c}\text { Sludge } \\
\text { volume }\end{array}$ & $\begin{array}{c}\text { Transportation } \\
\text { cost }\end{array}$ \\
\hline $\mathrm{km}$ & $\mathrm{kg} / \mathrm{m}^{3} \mathrm{~d}$ & $\mathrm{~kg} / \mathrm{m}^{3} \mathrm{~d}$ & $\mathrm{~m}^{3} / \mathrm{d}$ & PLN/d \\
\hline 25 & 25238 & 18929 & 168 & 16691 \\
\hline 50 & 30563 & 22922 & 204 & 24068 \\
\hline
\end{tabular}

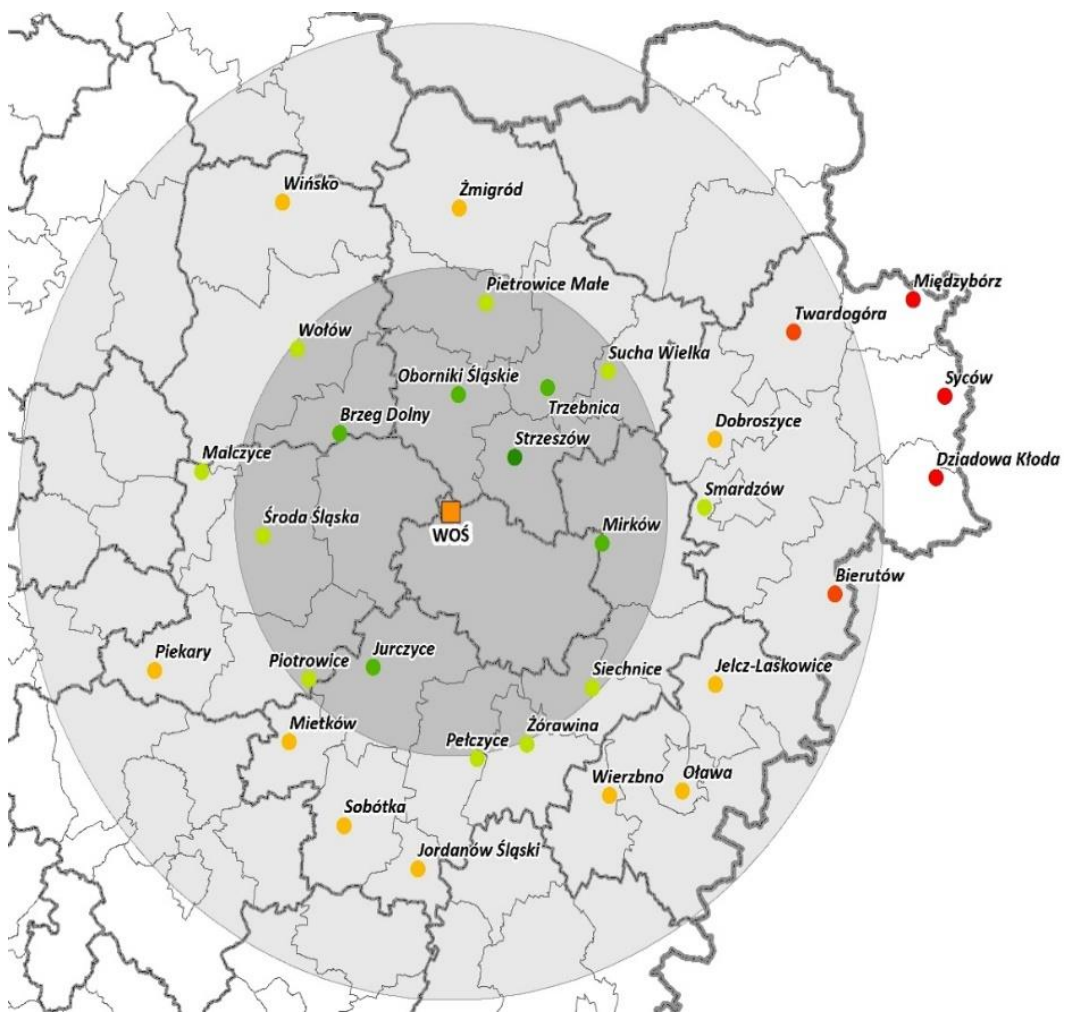

Fig. 2. Localization of analysed plants. 


\subsection{Increasing of gas production}

To estimate amount of gas produced and disintegration process effects it is necessary to divide gas production from primary and excess sludge streams at the Central Plant. It is generally known, that considering anaerobic digestion process there is no difference between excess sludge from WWTP with or without primary sedimentation [10]. For that reason, excess sludge streams from Central and smaller plants will be considered in similar way, regardless of primary sedimentation use in selected plants. Gas production efficiency rates for excess and primary sludge was assumed on 0.2 and $0.54 \mathrm{Nm}^{3} / \mathrm{kgVSS}_{\text {in }}$, respectively. In case of disintegration process used for excess sludge pre-treatment, gas production rate was higher $\left(0.3 \mathrm{Nm}^{3} / \mathrm{kgVSS}_{\text {in }}\right)$. Based on this information and data form Table 1, gas production was estimated. For excess sludge, it was about $3165 \mathrm{Nm}^{3} / \mathrm{d}$ and for primary sludge more than $16976 \mathrm{Nm}^{3} / \mathrm{d}$. Tab. 4 summarizes gas production analysis for all warrants. As expected, huge influence on amount of produced gas had potential use of disintegration process. Increase of gas production for " $50 \mathrm{D}$ " scenario reached $42 \%$ of the basic value. Amount of sludge from radius greater them $25 \mathrm{~km}$ and lower than $50 \mathrm{~km}$ is so small (only more than $5325 \mathrm{kgTSS} / \mathrm{d}$ its about $21 \%$ ) that gas production in " $25 \mathrm{D}$ " scenario is greater than in " 50 " scenario.

As the last step of performed analysis, impact of greater amount of excess sludge from smaller plants on digestion process at the Central Plant was investigated. New technological parameters were calculated for each of proposed scenarios.

Table 4. Gas production analysis.

\begin{tabular}{|c|c|c|c|c|c|c|c|c|c|}
\hline \multirow{3}{*}{ Var. } & \multicolumn{3}{|c|}{ Primary sludge } & \multicolumn{3}{|c|}{ Excess sludge } & \multicolumn{3}{|c|}{ Mixed sludge } \\
\hline & \multirow{2}{*}{\begin{tabular}{|c|}
$\mathrm{VSS}$ \\
$\mathrm{kgVSS} / \mathrm{d}$ \\
\end{tabular}} & \multicolumn{2}{|c|}{ Gas production } & \multirow{2}{*}{$\frac{\mathrm{VSS}}{\mathrm{kgVSS} / \mathrm{d}}$} & \multicolumn{2}{|c|}{ Gas production } & \multirow{2}{*}{\begin{tabular}{|c|}
$\mathrm{VSS}$ \\
$\mathrm{kgVSS} / \mathrm{d}$ \\
\end{tabular}} & \multicolumn{2}{|c|}{ Gas production } \\
\hline & & $\mathrm{m}^{3} / \mathrm{kgVSS}$ & $\mathrm{m}^{3} / \mathrm{d}$ & & $\mathrm{m}^{3} / \mathrm{kgVSS}$ & $\mathrm{m}^{3} / \mathrm{d}$ & & $\mathrm{m}^{3} / \mathrm{kgVSS}$ & $\%$ \\
\hline 0 & \multirow{6}{*}{31337} & \multirow{6}{*}{0.54} & \multirow{6}{*}{16976} & \multirow{2}{*}{15829} & 0.20 & 3166 & \multirow{2}{*}{47166} & 20142 & - \\
\hline 0D & & & & & 0.30 & 4749 & & 21725 & $8 \%$ \\
\hline 25 & & & & \multirow{2}{*}{34758} & 0.20 & 6952 & \multirow{2}{*}{66095} & 23928 & $19 \%$ \\
\hline $25 \mathrm{D}$ & & & & & 0.30 & 10427 & & 27403 & $36 \%$ \\
\hline 50 & & & & \multirow{2}{*}{38751} & 0.20 & 7750 & \multirow{2}{*}{70088} & 24726 & $23 \%$ \\
\hline $50 \mathrm{D}$ & & & & & 0.30 & 11625 & & 28602 & $42 \%$ \\
\hline
\end{tabular}

In Table 5 parameters for anaerobic digestion process for all scenarios were described. None of analysed parameters exceed the limit values mentioned before. HRT in the extreme scenarios ("50" and "50D") were below 24 days. That is safe value but in case of anaerobic digestion of wastewater sludge, long HRT is required considering excess sludge rather than primary sludge. Because transported sludge is dewatered, possibility of increasing sludge concentration in anaerobic digestion reactors above actual value exists. Currently, average sludge concentration in digesters is about $55-60 \mathrm{kgTSS} / \mathrm{m}^{3}$. Increasing the sludge concentration above $70 \mathrm{kgTSS} / \mathrm{m}^{3}$ allows you to prolong HRT up to 30 days.

OLR increased by $50 \%$ ("50" and " $50 \mathrm{D}$ ") to $1.8 \mathrm{kgVSS} / \mathrm{m}^{3} \mathrm{~d}$. Achieved value is not even close to limit value $\left(5.7 \mathrm{kgVSS} / \mathrm{m}^{3} \mathrm{~d}\right)$ and will not affect whole process. As expected, average gas production efficiency was slightly decreased 
Table 5. Technological parameters of anaerobic digestion process in selected scenarios.

\begin{tabular}{|c|c|c|c|c|c|c|}
\hline \multirow{2}{*}{ Var. } & \multicolumn{3}{|c|}{ Mixed sludge } & \multicolumn{3}{c|}{ Technological parameters } \\
\cline { 2 - 7 } & TSS & VSS & Gas prod. & HRT & OLR & Gas prod. \\
\cline { 2 - 7 } & $\mathrm{kgTSS} / \mathrm{m}^{3}$ & $\mathrm{kgVSS} / \mathrm{m}^{3}$ & $\mathrm{~m}^{3} / \mathrm{d}$ & $\mathrm{d}$ & $\begin{array}{c}\left.\mathrm{kgVSS}_{1}{ }^{3} \mathrm{~d}\right)^{-} \\
\mathrm{m}^{3} / \mathrm{kgVSS}\end{array}$ \\
\hline 0 & 62855 & 47166 & 20142 & 35.4 & 1.21 & 0.43 \\
\hline 0D & 62855 & 47166 & 21725 & 35.4 & 1.21 & 0.46 \\
\hline 25 & 88093 & 66095 & 23928 & 25.2 & 1.69 & 0.36 \\
\hline 25D & 88093 & 66095 & 27403 & 25.2 & 1.69 & 0.41 \\
\hline 50 & 93418 & 70088 & 24726 & 23.8 & 1.80 & 0.35 \\
\hline 50D & 93418 & 70088 & 28602 & 23.8 & 1.80 & 0.41 \\
\hline
\end{tabular}

\section{Conclusions}

- Wastewater sludge management overview in region revealed significant potential of available additional streams of sewage sludge in medium and small WWTP localized in a short distance from the Central Plant.

- Sewage sludge form analysed region do not fully cover the possibilities of anaerobic digestion process at the Central Plant. Anaerobic reactors on plant are much oversized. To cover the possibility of the process, it will be necessary to transport sewage sludge from a greater distance than assumed range of 50 kilometres. In author's opinion, such solution might not be economically justified but further analysis should be performed.

- Technological analysis confirmed that significant part of gas production comes from primary sludge. Incensement of excess sludge amount by 2.5 times do not change this situation and primary sludge will still have the biggest share in the overall gas production.

- Disintegration might improve gas production from excess sludge by $50 \%$. Significant increase of excess sludge amount will make the disintegration process more profitable, especially considering fact that the biggest cost factor in disintegration process implementation is the cost of buying a patented technology, not size of the specific installation.

- Transport of dewatered excess sludge form smaller WWTPs localized nearby has a lot of advantages. It is possible to use thermal-pressure disintegration, which requires dewatered sludge as influent. That solution eliminated of dewatering sludge on large WWTP before anaerobic digestion. Transport that kind of sludge also allow to increase sludge concentration in anaerobic digestion reactors and prevention of excessive HRT decrease. Dewatering also significantly lowers transport costs.

- When disintegration will be implemented, it is possible to increase gas production by over $40 \%$ It should significantly improve the energetic balance of the large WWTP.

- There are no reports in literature about use sludge from several objects in co-digested in one plant.

This research are co-financed by Municipal Support Program for Higher Education, Science and Sector of Economic Activity MOZART" edition 2016/2017. 


\section{References}

1. Polityka Energetyczna Polski, Ministerstwo Gospodarki (2010)

2. G. Berent-Kowalska, J. Kacprowska, I. Moskal, A. Jurgas, Energia ze źródeł odnawialnych w Polsce, GUS (2015)

3. A. Costa, Ch. Ely, M. Pennington, S. Rock, C. Staniec, J. Turgeon, Anaerobic Digestion and its Applications, (EPA/600/R-15/304 2015)

4. R. Braun, A. Wellinger, Potential of Co-digestion (IEA Bioenergy 2007)

5. G. Esposito, L. Frunzo, A. Giordano, F. Liotta, A. Panico, F. Pirozzi, Rev. Environ. Sci. Biotechnol. 11, 325-341 (2012)

6. G. Tchobanoglous, Wastewater Engineering: Treatment Reuse (Metcalf \& Eddy, Inc. 2003)

7. J. Bień, Osady Ściekowe Teoria i Praktyka (Częstochowa 2002)

8. Environmental Regulations and Technology: Control of Pathogens and Vector Attraction in Sewage Sludge (EPA; Cincinnati 2003)

9. The National Program for Municipal Waste Water Treatment (NPMWWT) from years 2014-2015 (KZGW 2016)

10. K. Iskra, S. Miodoński, Gaz, Woda i Technika Sanitarna 5, 184-188 (2015)

11. C. Bougriera, C. Albasib, J.P. Delgenèsa, H. Carrèrea, Chem. Eng. Process 45, 711-718 (2006) 